\title{
6. Do the coastal states in the South China Sea have a continental shelf beyond 200 nautical miles?
}

\section{Alex Oude Elferink}

\section{INTRODUCTION ${ }^{1}$}

The United Nations Convention on the Law of the $\mathrm{Sea}^{2}$ recognizes two bases of continental shelf entitlement: up to a distance of 200 nautical miles $(\mathrm{nm})^{3}$ or to the outer edge of the continental margin, where the margin extends beyond that distance. ${ }^{4}$ The distance of the mainland coast

1 This chapter in part is based on earlier research that has been reported in a number of publications. This concerns AG Oude Elferink, 'The Regime for Marine Scientific Research in the Arctic: Implications of the Absence of Outer Limits of the Continental Shelf beyond 200 Nautical Miles' in S Wasum-Rainer, I Winkelmann and K Tiroch (eds), Arctic Science, International Law and Climate Change; Legal Aspects of Marine Science in the Arctic Ocean (Berlin: Springer Verlag, 2012) 189; AG Oude Elferink, 'Causes, Consequences and Solutions Relating to the Absence of Final and Binding Outer Limits of the Continental Shelf' in CR Symmons (ed), Selected Contemporary Issues in the Law of the Sea (Leiden: Martinus Nijhoff Publishers, 2011) 253; AG Oude Elferink, 'The Continental Shelf in the Polar Regions: Cold War or Black-Letter Law?' (2009) XL Netherlands Yearbook of International Law 121; and AG Oude Elferink, The Options to Deal with a Deadlock in the Consideration of a Submission by the Commission on the Limits of the Continental Shelf (paper presented at the Colloquium on the Outer Limits of the Continental Shelf and Consideration of Submissions to the Commission on the Limits of the Continental Shelf, Kuala Lumpur, 10 and 11 May 2010; on file with the author).

2 United Nations Convention on the Law of the Sea, adopted 10 December 1982, 1833 UNTS 397 (entered into force 16 November 1994) (UNCLOS), online: http://www.un.org/Depts/los/convention_agreements/convention_overview_conv ention.htm.

3 As Art 76(1) of UNCLOS indicates this concerns a distance of $200 \mathrm{~nm}$ from the baselines from which the breadth of the territorial sea is measured.

4 UNCLOS, Art 76(1). All of the States surrounding the South China Sea proper (excluding the Gulf of Thailand) Brunei Darussalam (hereinafter Brunei), Indonesia, Malaysia, the Philippines, the People's Republic of China (hereinafter 
of Viet Nam to the islands of Borneo and Palawan is over $500 \mathrm{~nm}$ and that to Luzon, the largest island in the Philippines, is well over $600 \mathrm{~nm}$. The continental margin in the South China Sea extends beyond $200 \mathrm{~nm}$. These facts would seem to indicate that there can be no doubt about a positive answer to the question contained in the title of this chapter. However, it obviously is not that simple. This is due to the presence of a number of island groups in the South China Sea: the Paracel Islands, the Spratly Islands, and the features on Scarborough Reef. International law indicates that islands in principle have the same entitlement to a continental shelf as continental coasts. The only exception is formed by rocks as defined in Article 121(3) of UNCLOS. Due to the location of the Paracel Islands, the Spratly Islands, and the features on Scarborough Reef, the entire area that is beyond $200 \mathrm{~nm}$ of the coasts surrounding the South China Sea is within $200 \mathrm{~nm}$ of these islands. This raises a number of legal questions. Most importantly, this concerns the relationship between the $200 \mathrm{~nm}$ zone of the islands and the continental shelf beyond $200 \mathrm{~nm}$ generated by the surrounding coasts. ${ }^{5}$ If the continental shelf beyond $200 \mathrm{~nm}$ co-exists with the $200 \mathrm{~nm}$ zone, further questions concern the implications of this co-existence for the water column rights in the exclusive economic zone (EEZ) and the delimitation of the continental shelf.

Three of the coastal States of the South China Sea, Brunei, Malaysia and Viet Nam, have already indicated that they consider that their mainland coasts are entitled to a continental shelf beyond $200 \mathrm{~nm}$ and have made or intend making a submission to the Commission on the Limits of the Continental Shelf (CLCS) in relation to the outer limits of this continental shelf. China and the Philippines have reserved their rights in this respect. This indicates that the questions identified above merit further consideration. In looking at these questions, this chapter starts by giving an overview of Article 76 of UNCLOS on the definition on the continental shelf (section II). Section III will review the steps that Brunei, China, Malaysia, the Philippines and Viet Nam have taken thus far to implement Article 76 in relation to the South China Sea. China and the Philippines have objected to the consideration of the submissions that Malaysia and Viet Nam have made to the CLCS. This implies that the Commission is

China) and Viet Nam are parties to UNCLOS. This chapter does not consider the position of the Republic of China.

5 This chapter does not address the question whether or not the Paracel Islands, the Spratly Islands, and the features on Scarborough Reef fall under Art 121(3) of UNCLOS. However, I consider that the larger islands in the Paracel and Spratly Islands do not fall under this provision and thus are entitled to a continental shelf and an exclusive economic zone (EEZ). 
not in a position to consider these submissions. Section IV of the chapter considers the steps that Malaysia and Viet Nam could take to deal with this deadlock. Section V looks at the legal status of the continental shelf beyond $200 \mathrm{~nm}$ in the absence of final and binding limits established in accordance with Article 76 of UNCLOS. The implications of the presence of the Paracel Islands and the Spratly Islands for the entitlement to and delimitation of the continental shelf beyond $200 \mathrm{~nm}$ will be considered in section VI. Section VII contains concluding remarks.

\section{ARTICLE 76 OF UNCLOS 6}

Article 76 of UNCLOS is a compromise made during the Third UN Conference on the Law of the Sea between States with a broad continental margin extending beyond $200 \mathrm{~nm}$ and States wishing to limit the extent of coastal State jurisdiction to safeguard a larger part of the seabed as the common heritage of mankind. Article 76 to a large extent reflects the interests of the broad margin States, also dubbed margineers, which included a number of influential States, such as Australia, Canada and the United States. The main achievement of Article 76 is that it should allow arriving at final and stable boundaries between the continental shelf and the international seabed area, referred to as the Area in UNCLOS, and to finally resolve the uncertainty that has existed in this respect for decades.

Article 76(1) defines the continental shelf as the natural prolongation of the land territory of the coastal State to the outer edge of the continental margin, or to a distance of $200 \mathrm{~nm}$, where the outer edge of the continental margin does not extend up to that distance. The subsequent paragraphs of Article 76 contain specific criteria to establish the outer edge of the

6 For a more detailed discussion of various aspects of Art 76, see $\mathrm{MH}$ Nordquist, general ed, United Nations Convention on the Law of the Sea 1982: A Commentary (6 Volumes) (Leiden: Martinus Nijhoff Publishers: 1985, 1989, 1991, 1993, 2002) Vol II, 825-890 and 1000-1025; MH Nordquist, J Norton Moore and TH Heidar, eds, Legal and Scientific Aspects of Continental Shelf Limits (Leiden: Martinus Nijhoff Publishers, 2004); TL McDorman, 'The Role of the Commission on the Limits of the Continental Shelf: A Technical Body in a Political World' (2002) 17 Int'1 J Mar \& Coast L 301; Committee on Legal Issues of the Outer Continental Shelf , 'Second Report' in International Law Association, Report of the Seventy-Second Conference (London, 2006) 215; SV Suarez, The Outer Limits of the Continental Shelf; Legal Aspects of their Establishment (Berlin: Springer Verlag, 2008); VJM Tassin, Les défis de l'extension du plateau continental; La consécration d'un nouveau rapport de l'Etat à son territoire (Paris: Editions A Pedone, 2013). 
continental margin beyond $200 \mathrm{~nm}$. The outer edge of the margin defined in accordance with Article 76 is the outer limit of the continental shelf beyond $200 \mathrm{~nm}$.

The establishment of the outer limits of the continental shelf beyond 200 $\mathrm{nm}$ first of all requires a coastal State to determine the foot of the continental slope. ${ }^{7}$ Article $76(4)(b)$ provides that the foot of the continental slope, in the absence of evidence to the contrary, shall be determined as the point of maximum change in the gradient at its base. From these points at the foot of the slope a coastal State can then determine fixed points to define the outer limit of the continental shelf. ${ }^{8}$ The coastal State in this connection can employ two formulae. A fixed point in any case can be established at a distance of $60 \mathrm{~nm}$ from a point at the foot of the continental slope. If the sedimentary rocks of the continental margin have a certain thickness, fixed points can be located beyond that distance. A specific point may be used if the thickness of sedimentary rocks is at least 1 per cent of the shortest distance from such a point to the foot of the slope. ${ }^{9}$

Fixed points which have been established in accordance with Article 76(4) may only be employed to define the outer limit of the continental shelf if they meet a number of additional criteria. First of all, these points shall not exceed: (a) $350 \mathrm{~nm}$ from the baselines from which the breadth of the territorial sea is measured; or (b) $100 \mathrm{~nm}$ from the 2,500 meter isobath. ${ }^{10}$ In certain cases a coastal State is only entitled to use the $350-\mathrm{nm}$ line. ${ }^{11}$ In view of the geography of the South China Sea, these constraints are likely to have limited or no significance for its coastal States. Fixed points which meet the conditions contained in Article 76(4) to (6) may be employed to define the outer limit of the continental shelf beyond $200 \mathrm{~nm}$. These fixed points may not be more than $60 \mathrm{~nm}$ apart. ${ }^{12}$

Before establishing the outer limit on the basis of the above criteria, a coastal State is required to submit information concerning those limits to the CLCS within 10 years of having become a Party to the Convention. ${ }^{13}$ In 2001, the 11th Meeting of States Parties to the Convention decided that

7 The continental slope is one of the three features making up the continental margin as defined by Art 76(3) of UNCLOS, the other two being the shelf and the rise. The slope is located between the shelf and the rise.

8 UNCLOS, Art 76(4)(a).

9 Ibid. This second formula was included in Art 76 because it was considered that it would ensure that most exploitable hydrocarbon resources would be located in the continental shelf and not in the Area.

10 UNCLOS, Art 76(5).

11 UNCLOS, Art 76(6).

12 UNCLOS, Art 76(7).

13 UNCLOS, Annex II, Art 4. 
for States which had become a Party to the Convention before 13 May 1999, the period of 10 years would start to run on that date. ${ }^{14} \mathrm{~A}$ decision of the 18th Meeting of States Parties to the Convention in June 2008 in addition created the possibility for States to submit preliminary information. ${ }^{15}$ This procedure is in particular intended to address the difficulties of developing States meeting the 10 -year time limit for making a submission. The decision of the Meeting of States Parties established that States comply with this requirement by submitting preliminary information. Preliminary information need not contain information on the exact location of the outer limits of the continental shelf and the Commission will not consider this information pending the State making a full submission.

The limits of the continental shelf established by the coastal State on the basis of the recommendations of the Commission are final and binding. ${ }^{16}$ In the case of disagreement with the recommendations of the Commission,

14 Decision regarding the Date of Commencement of the Ten-Year Period for Making Submissions to the Commission on the Limits of the Continental Shelf Set Out in Article 4 of Annex II to the United Nations Convention on the Law of the Sea (SPLOS/72 of 29 May 2001), online: daccess-dds-ny.un.org/doc/UNDOC/ GEN/N01/387/64/PDF/N0138764.pdf?OpenElement.

15 Decision regarding the workload of the Commission on the Limits of the Continental Shelf and the ability of States, particularly developing States, to fulfil the requirements of Article 4 of Annex II to the Convention, as well as the decision contained in SPLOS/72, paragraph (a) (SPLOS/183 of 20 June 2008), online: daccess-dds-ny.un.org/doc/UNDOC/GEN/N08/398/76/PDF/N0839876. pdf?OpenElement. For an analysis of the decision see AG Oude Elferink, 'The Time Limit for Making Submissions to the Commission on the Limits of the Continental Shelf - the Current State of Affairs' (2008) 23 Int'l J Mar \& Coast L 769.

16 UNCLOS, Art 76(8). During the Roundtable the question was raised upon whom outer limits are final and binding (Verbatim Record of Session 6 of the CIL Roundtable on the South China Sea, International Law and UNCLOS, Singapore, 27-28 June 2013). One view was that they only become final and binding on the coastal State (Verbatim Record, Session 6, at 11-12). Another participant observed that he did not believe that there would be any point requiring the coastal State to go to enormous expense in preparing a submission for the sole purpose of binding only itself (Verbatim Record, Session 6, at 18). I agree with the second view. As has been pointed out elsewhere '[o]nly the coastal State is competent to establish the outer limit of its continental shelf. It would thus be impossible for an outer limit line that is final and binding on the coastal State not to be binding on other States or be subject to change'; see Committee on Legal Issues of the Outer Continental Shelf, 'Report' supra note 6 at 233. It should, however, also be noted that outer limits do no automatically become binding upon their establishment by the coastal State. Other States can object to such limits on substantive and/or procedural grounds; see further ibid, at 233 and 245-248. Without the resolution of a dispute in relation to an outer limit it will not become final and binding. 
the Convention requires a coastal State to make a new or revised submission within a reasonable time. ${ }^{17}$

The Commission is charged with considering the data and other material submitted by a coastal State in support of the proposed outer limit lines of the continental shelf beyond $200 \mathrm{~nm} .{ }^{18}$ The Commission, which consists of 21 members, in that connection is primarily required to consider the scientific and technical aspects of the implementation of Article 76 by coastal States. The Convention requires that members of the Commission are experts in the field of geology, geophysics or hydrography. ${ }^{19}$

Article 76(10) establishes that the provisions of Article 76 are without prejudice to the delimitation of the continental shelf between neighbouring States. Paragraph 10 implies that final and binding limits established in accordance with Article 76(8) are not opposable in relation to a neighbouring State. Article 9 of Annex II to the Convention provides that the actions of the Commission shall not prejudice matters relating to the delimitation of boundaries between neighbouring States. A significant difference between Article 76(10) and Article 9 of Annex II is that Article $76(10)$ implies Article 76 is without prejudice to the delimitation of boundaries. It does not prescribe a specific course of action for the coastal State making the submission or the Commission. On the other hand, Article 9 does not indicate that the actions of the Commission are without prejudice to matters related to boundaries, but instead instructs the Commission to ensure that no such prejudice results from its actions.

The Commission has implemented the requirement of Article 9 of Annex II through its Rules of Procedure. ${ }^{20}$ Rule 46 provides for a procedure for handling submissions by coastal States in relation to which there is a dispute concerning the delimitation of the continental shelf or other maritime or territorial disputes. ${ }^{21}$ This procedure, which is contained in

\footnotetext{
17 UNCLOS, Annex II, Art 8.

18 UNCLOS, Annex II, Art 3.

19 UNCLOS, Annex II, Art 2(1).

20 Rules of Procedure of the Commission on the Limits of the Continental Shelf (hereinafter Rules of Procedure). The current version of the Rules of Procedure is contained in CLCS/40 Rev.1 of 17 April 2008, online: http://daccess-dds-ny. un.org/doc/UNDOC/GEN/N08/309/23/PDF/N0830923.pdf?OpenElement.

21 Rule 46 of the Rules of Procedure provides:
}

1. In case there is a dispute in the delimitation of the continental shelf between opposite or adjacent States or in other cases of unresolved land or maritime disputes, submissions may be made and shall be considered in accordance with Annex I to these Rules.

2. The actions of the Commission shall not prejudice matters relating to the delimitation of boundaries between States. 
Annex I to the Rules of Procedure, allows a State to limit its submission to a specific area or to make a joint submission with neighbouring States. ${ }^{22}$ Annex I furthermore provides that, in a case in which a dispute exists, the Commission will only consider the submission of a coastal State with the prior consent of all States that are parties to the dispute. ${ }^{23}$ To offer other States the opportunity to establish whether there exists a dispute related to the submission of a coastal State, the latter is required to draw up an executive summary of the submission, which is published after the submission has been made. ${ }^{24}$

\section{THE COASTAL STATES OF THE SOUTH CHINA SEA AND ARTICLE 76}

Five of the six coastal States of the South China Sea could make a submission on the continental shelf beyond $200 \mathrm{~nm}$ to the CLCS. ${ }^{25}$ The only State that is excluded from doing so is Indonesia, because its continental shelf is delimited by boundaries with neighbouring States that are located in their entirety within $200 \mathrm{~nm}$ from Indonesia's baselines. Malaysia and Viet Nam have made a joint submission to the CLCS for the southern part of the South China Sea. ${ }^{26}$ Viet Nam in addition has made a submission for an area to the southeast of the Paracel Islands. ${ }^{27}$ Brunei has not made a submission to the Commission, but has submit-

\footnotetext{
22 Rules of Procedure, Annex I, paras 3-4.

23 Rules of Procedure, Annex I, para 5.

24 Rules of Procedure, Rule 50.
}

25 For a discussion of the implementation of Art 76 by the coastal States of the South China Sea and its impact on regional cooperation see Ted L McDorman 'The South China Sea After 2009: Clarity of Claims and Enhanced Prospects for Regional Cooperation?' (2010) 24 Ocean Yearbook 507.

26 Malaysia and the Socialist Republic of Viet Nam, Joint submission to the Commission on the Limits of the Continental Shelf, in accordance with Article 76, paragraph 8, of the United Nations Convention on the Law of the Sea in respect of the southern part of the South China Sea; Executive Summary (hereinafter Joint Submission), online: www.un.org/Depts/los/clcs_new/submissions_files/ mysvnm33_09/mys_vnm2009excutivesummary.pdf.

27 Socialist Republic of Viet Nam, Submission to the Commission on the Limits of the Continental Shelf pursuant to Article 76, paragraph 8, of the United Nations Convention on the Law of the Sea; Partial submission in respect of Viet Nam's Extended Continental Shelf; North Area (NMV-N); Executive Summary (hereinafter Submission for the North Area), online: www.un.org/Depts/los/ clcs_new/submissions_files/vnm37_09/vnm2009n_executivesummary.pdf. 
ted preliminary information on the outer limits of its continental shelf in the South China Sea. ${ }^{28}$

China and the Philippines have neither made a submission to the CLCS nor submitted preliminary information in relation to the South China Sea. However, both States have left open the option that they will make a submission at a later date. In making a submission in relation to the East China Sea in December 2012, China observed that this concerned a partial submission that was without prejudice to any future submission of China in the East China Sea 'and other seas'. ${ }^{29}$ The only other sea for which China could make a submission is the South China Sea. ${ }^{30}$ Similarly, the Philippines, in making a submission for the Benham Rise region in the Pacific, observed that it reserved its right to make other submissions for other areas of continental shelf beyond $200 \mathrm{~nm} .{ }^{31}$ Just as is the case for China, the only other sea to which this statement could apply is the South China Sea. The making of a partial submission is not envisaged by UNCLOS but is provided for in the Rules of Procedure of the CLCS. ${ }^{32}$ The Rules of Procedure do not indicate a timeline for making a further submission where a partial submission has been made. Presumably, as

28 Brunei Darussalam's Preliminary Submission concerning the Outer Limits of its Continental Shelf (hereinafter Preliminary Submission Brunei), online: www. un.org/Depts/los/clcs_new/submissions_files/preliminary/brn2009preliminaryin formation.pdf.

29 Submission by the People's Republic of China concerning the outer limits of the continental shelf beyond 200 nautical miles in part of the East China Sea; Executive Summary, at 2, online: www.un.org/Depts/los/clcs_new/submissions_files/chn63_12/executive\%20summary_EN.pdf. China had earlier taken the same position in submitting preliminary information on the East China Sea in May 2009, see Preliminary Information Indicative of the Outer Limits of the Continental Shelf Beyond 200 Nautical Miles of the People's Republic of China, at 5, online: www.un.org/Depts/los/clcs_new/submissions_files/preliminary/chn2009preliminaryinformation_english.pdf.

30 See also McDorman, supra note 25, at 516. Viet Nam's submission for the North Area seems to recognize implicitly that China has a continental shelf entitlement beyond $200 \mathrm{~nm}$ from Hainan Island (see further infra note 34).

31 A partial submission of data and information on the outer limits of the continental shelf of the Republic of the Philippines pursuant to Article 76(8) of the United Nations Convention on the Law of the Sea; Executive Summary, at 12, online: www.un.org/Depts/los/clcs_new/submissions_files/ph122_09/phl_esummary.pdf. The Executive Summary observes that this approach is chosen 'to avoid creating or provoking maritime boundary disputes where there are none, or exacerbating them where they may exist, in areas where maritime boundaries have not yet been delimited between opposite or adjacent coastal States', see ibid.

32 Rules of Procedure, Annex I, para 3, supra note 20. 
long as the reasons that gave rise to making a partial submission continue to exist, there will be no obligation to make a further submission.

Malaysia and Viet Nam made their joint submission to the CLCS for an area in the southern part of the South China Sea on 6 May 2009 and Viet Nam made its submission for an area to the east of its mainland coast, which it identifies as the North Area, on 7 May 2009. ${ }^{33}$ One of the most striking aspects of both these submissions is that they define the $200 \mathrm{~nm}$ limit of Malaysia and Viet Nam without reference to the disputed islands in the South China Sea. The entire area contained in the two submissions is within $200 \mathrm{~nm}$ of either the Spratly Islands or the Paracel Islands. Viet Nam claims sovereignty over both island groups and Malaysia claims sovereignty over part of the Spratly Islands. Not using the islands to define the extent of their maritime zones could mean a number of things. First, Malaysia and Viet Nam may consider that the islands fall under the definition of rocks contained in Article 121(3) of UNCLOS or they may have wanted to demonstrate that their continental shelf extends into the area concerned, regardless of how the sovereignty disputes over the islands would be resolved. The extent of the area covered by the two submissions suggests another explanation for the approach of Malaysia and Viet Nam. An implicit message of the submissions would seem to be that the islands should be completely disregarded in the delimitation of continental shelf boundaries between neighbouring States. ${ }^{34}$

As far as Annex I to the Rules of Procedure of the CLCS is concerned, the outer limits contained in the joint submission of Malaysia and Viet Nam and Viet Nam's submission in relation to the North Area not only concern overlapping continental shelf entitlements in relation to the Paracel Islands and the Spratly Islands. In the case of Viet Nam's submission there also exists a potential overlap with the continental shelf extending from China's

33 For a more detailed discussion of the submissions, including the reaction of other States and their presentation to the CLCS, see Oude Elferink, Options, supra note 1.

34 The Executive Summary of Viet Nam's submission for the North Area indicates that the northern terminus of the outer limit of the continental shelf beyond $200 \mathrm{~nm}$ submitted to the CLCS is located on an equidistance line, see Submission for the North Area, Executive Summary, 6, supra note 27. This concerns a point that seems to be equidistant between China's island of Hainan and Viet Nam's straight baseline along its mainland coast. The Paracel Islands are much closer to this outer limit point than these other coasts. Similarly, outer limit point 1 of the joint submission by Malaysia and Viet Nam is on a point that is equidistant between points that are $200 \mathrm{~nm}$ from the coast of Malaysia and the Philippines, see Joint Submission, executive summary, 6, supra note 26. This point is much closer than $200 \mathrm{~nm}$ to the Spratly Islands. 
Hainan Island and in the case of the joint submission there exists a potential overlap with the continental shelf of Brunei and that of the Philippines. In the latter case, the territorial dispute over Sabah between Malaysia and the Philippines also falls under Annex I of the Rules of Procedure of the CLCS. All these issues required Viet Nam and Malaysia to consider how to deal with the requirement contained in the Commission's Scientific and Technical Guidelines that the executive summary of a submission has to contain information on disputes as referred to in Annex I to the Rules of Procedure of the Commission. ${ }^{35}$ The executive summary of Viet Nam's submission and the joint submission took a similar approach in this respect. The executive summary of the joint submission informed the Commission that there were unresolved disputes in the area defined in the submission. ${ }^{36}$ At the same time, the Commission was assured that to the extent possible the joint submission will not prejudice matters related to the delimitation of boundaries between States with opposite and adjacent States. ${ }^{37}$ Finally, section 4.3 of the executive summary of the joint submission indicates that Malaysia and Viet Nam have undertaken efforts to secure the non-objection of the other relevant coastal States. Such non-objection would be required to allow the Commission to consider the submission and to issue recommendations. Malaysia and Viet Nam also affirmed that the joint submission was in consonance with paragraph 5(b) of Annex I to the Rules of Procedure. The reference of Malaysia and Viet Nam to paragraph 5(b) seems to imply that Malaysia and Viet Nam held that the Commission should consider the joint submission, even though the requirement of paragraph 5(a) - prior consent of all States that are parties to such a dispute - had not been met.

Viet Nam in the executive summary of its submission in relation to the North Area included a section 'Absence of disputes'. This section first observed that:

Viet Nam wishes to inform the Commission that there is a common understanding that the area of continental shelf which is the subject of this Submission is of overlapping interests expressed by relevant coastal states. Nevertheless, subject to the provisions of UNCLOS 1982, Viet Nam is of the view that the area of continental shelf that is the subject of this Submission is not subject to any overlap and dispute. ${ }^{38}$

35 Scientific and Technical Guidelines of the Commission on the Limits of the Continental Shelf (CLCS/11 of 13 May 1999), at para 9.1.4, online: http://daccessdds-ny.un.org/doc/UNDOC/GEN/N99/171/08/IMG/N9917108.pdf?OpenElement.

36 Joint Submission, Executive summary, section 4.1, supra note 26.

37 Ibid, section 4.2.

38 Submission for the North Area, Executive summary, section 4, supra note 27. 
The executive summary further indicated that the submission was without prejudice to the maritime delimitation of Viet Nam and other relevant coastal States and that Viet Nam had undertaken efforts to secure the non-objection of other coastal States. ${ }^{39}$ The latter observation indicates that Viet Nam was aware of the possibility that other States might object to the consideration of its submission, while invoking Annex I to the Rules of Procedure of the CLCS.

The joint submission and Viet Nam's submission for the North Area led to an almost immediate reaction from China. China indicated that it considered that the submissions 'seriously infringed China's sovereignty, sovereign rights and jurisdiction in the South China Sea', and requested that the Commission, in accordance with paragraph 5(a) of Annex I to its Rules of Procedure, not consider the two submissions. ${ }^{40}$ Three months later, the Philippines indicated that the joint submission concerned areas that were disputed because of overlapping continental shelf claims and the controversy arising from territorial claims including that over North Borneo. ${ }^{41}$ In relation to Viet Nam's submission for the North Area the Philippines only referred to the former point. ${ }^{42}$ The Philippines requested the Commission not to consider the two submissions until after the disputes to which the Philippines referred in its Notes Verbales had been discussed and resolved. ${ }^{43}$

It can be noted that neither China nor the Philippines in their Notes refer to the fact that the joint submission of Malaysia and Viet Nam and the submission of Viet Nam are concerned with areas which are within 200 $\mathrm{nm}$ of the disputed islands in the South China Sea. Two explanations for the Chinese position can be entertained. If China's position is based on a claim to the waters of the South China Sea as historic waters, the status of the islands under Article 121(3) of UNCLOS is not an issue. Secondly, China in respect of the East China Sea takes the position that its continental shelf beyond $200 \mathrm{~nm}$ extends to an area that is within $200 \mathrm{~nm}$ of Japan.

\section{Ibid.}

40 See Note Verbale CML/17/2009 of 7 May 2009, online: www.un.org/Depts/ los/clcs_new/submissions_files/mysvnm33_09/chn_2009re_mys_vnm.pdf; Note Verbale CML/18/2009 of 7 May 2009, online: www.un.org/Depts/los/clcs_new/ submissions_files/vnm37_09/chn_2009re_vnm.pdf.

41 Note Verbale No 000819 of 4 August 2009, at 1, online: www.un.org/Depts/ los/clcs_new/submissions_files/vnm37_09/chn_2009re_vnm.pdf. North Borneo, the eastern part of Sabah, one of the member states of the Malaysian federation, is also claimed by the Philippines.

42 Note Verbale No 000818 of 4 August 2009, 1, online: www.un.org/Depts/ los/clcs_new/submissions_files/vnm37_09/clcs_37_2009_los_phl.pdf.

43 Ibid, at 2; Note Verbale No 000819 , supra note $4 \overline{1}$, at 2 . 
If China were to take a different position in the South China Sea, it would expose itself to the risk of being accused of inconsistency. The Philippines, like Viet Nam and Malaysia, would not seem to have an interest in arguing the significance of the disputed islands in relation to maritime entitlements and delimitation. ${ }^{44}$

Viet Nam and Malaysia reacted to the Notes of China and the Philippines through diplomatic notes and in the presentation of the submissions to the CLCS. $^{45}$ All four Notes indicate that the submissions constitute a legitimate undertaking in the implementation of the obligations of States Parties to UNCLOS, which conform to the pertinent provisions of the Convention as well as the Rules of Procedure of the CLCS. In its Note reacting to China, Malaysia furthermore observes that the joint submission is made without prejudice to the question of the delimitation of the continental shelf and that the joint submission is without prejudice to the position of States which are parties to a land or maritime dispute as mentioned in paragraph 5(b) of Annex I to the Rules of Procedure of the Commission.

The Malaysian Note in reaction to the Philippine Note concludes by specifically requesting the Commission to consider the joint submission of Viet Nam and Malaysia. The other Notes in reaction to the Notes of China and the Philippines do not explicitly make this request.

The joint submission of Malaysia and Viet Nam was presented during the 24th session of the Commission on 27 August 2009 and Viet Nam made its presentation in respect of the North Area one day later. ${ }^{46}$ During the presentations, the views of Malaysia and Viet Nam on the matter of disputes as expressed in the executive summary of the submissions and the Notes Verbales were reiterated. ${ }^{47}$ The presentation on the

44 This point would seem to be confirmed by the application of the Philippines instituting arbitral proceedings under Annex VII of UNCLOS against China (Notification and Statement of Claims of 22 January 2013), online: https:// www.dfa.gov.ph/index.php/component/docman/doc_download/56-notificationand-statement-of-claim-on-west-philippine-sea?Itemid $=546$.

45 Note Verbale HA 24/09 of 20 May 2009 (reaction of Malaysia to China); Note Verbale HA41/09 of 21 August 2009 (reaction of Malaysia to the Philippines); Note Verbale No 86/HC-2009 of 8 May 2009 (reaction of Viet Nam to China); Note Verbale No 240/HC-2009 of 18 August 2009 (reaction of Viet Nam to the Philippines).

46 A summary of the presentations is contained in the statement by the Chairman of the Commission on the progress of work in the Commission at the 24th session (CLCS/64 of 1 October 2009), at paras 87-91 and 102-105, online: http:// daccess-dds-ny.un.org/doc/UNDOC/GEN/N09/536/21/PDF/N0953621.pdf?Open Element.

47 See $i b i d$, at paras 90-91 and 104-105. 
joint submission also indicated that the territorial disputes which were mentioned by China and the Philippines had no basis under international law. ${ }^{48}$ Viet Nam in its presentation of its submission for the North Area observed that it had indisputable sovereignty over the Paracel and Spratly Islands. ${ }^{49}$ These remarks may have been intended to imply that the territorial disputes cannot qualify as disputes in the sense of paragraph 5(a) of the Rules of Procedure of the Commission. However, in view of the Commission's deference to the competence of States as far as land and maritime disputes are concerned, it seems unlikely that it would disregard the views of China and the Philippines in this respect. ${ }^{50}$ The presentations emphasized that the submissions were without prejudice to the question of delimitation between States and that paragraph 5(a) of Annex I of the Rules of Procedure should not be invoked. ${ }^{51}$

Following the presentation of the submissions, the Commission addressed the modalities for their consideration. The Commission for the time being deferred on how it would further handle the two submissions. ${ }^{52}$

Brunei submitted preliminary information on the outer limits of its continental shelf beyond $200 \mathrm{~nm}$ in the South China Sea in May 2009.53 The preliminary information indicates that Brunei has delimited its EEZ and continental shelf up to $200 \mathrm{~nm}$ through an exchange of letters with

48 Ibid, at para 91.
49 Ibid, at para 105

50 Paragraph 1 of Annex I to the Rules of Procedure of the Commission provides 'The Commission recognizes that the competence with respect to matters regarding disputes which may arise in connection with the establishment of the outer limits of the continental shelf rests with States', supra note 20. For a discussion of practice of the Commission that is relevant for considering the approach it might take in respect of the positions of China, Malaysia, the Philippines and Viet Nam in relation to the consideration of the Joint Submission and the Submission for the North Area, see infra notes 60 and 61.

51 See CLCS/64 of 1 October 2009, at paras 91 and 105.

52 The statement by the chairman of the Commission observes in this respect that "the Commission decided to defer further consideration of the submission and the notes verbales until such time as the submission is next in line for consideration as queued in the order in which it was received. The Commission took this decision in order to take into consideration any further developments that might occur throughout the intervening period during which States may wish to take advantage of the avenues available to them including provisional arrangements of a practical nature as contained in annex I to its rules of procedure', ibid, at paras 92 and 106. For a discussion of the decision of the Commission see below.

53 Preliminary Submission Brunei. Reportedly, Brunei had accepted an invitation to be part of the joint submission of Malaysia and Viet Nam, but no explanation was provided as to why Brunei in the end did not sign on to the joint submission, see McDorman, supra note 25, at 521. 
Malaysia of 16 March 2009. ${ }^{54}$ The preliminary information does not indicate the provisional outer limits of Brunei's continental shelf, but its description of the continental margin indicates that Brunei's submission may cover the same area as that contained in the joint submission of Malaysia and Viet Nam and the area to the north of the latter area. ${ }^{55}$ The preliminary information indicates that it is made without prejudice to the delimitation of maritime boundaries with other States. ${ }^{56}$ Brunei indicated that it expected to make a full submission within 12 months of the submission of its preliminary information, ${ }^{57}$ but to date has not yet done so.

\section{THE CURRENT STATUS OF THE SUBMISSIONS OF MALAYSIA AND VIETNAM}

The decisions of the Commission at its 24th session in relation to the modalities for the consideration of the two submissions involving Malaysia and Viet Nam - deferral of a decision until the submissions are next in line for consideration by a sub-commission - are in line with its general policy in respect of submissions involving land and maritime disputes. The Commission has recognized that the competence with respect to matters regarding disputes which may arise in connection with the establishment of the outer limits of the continental shelf rests with States. ${ }^{58}$ In that light, it stands to reason to defer a decision on the modalities for considering the two submissions. The joint submission of Malaysia and Viet Nam is ranked 33rd on the list of submissions and the submission of Viet Nam is ranked 37th. In view of the current workload

54 Ibid, at 3. The Exchange of Letters took place in Bandar Seri Begawan, the capital of Brunei Darussalam. See: Ministry of Foreign Affairs of Malaysia (Wisma Putra), Press Statement (3 May 2010). The text of the Letters had not been publicly released by either government at the time this chapter was being prepared.

55 See Preliminary Submission Brunei, supra note 28, at 6. The Preliminary submission indicates that in making a full submission Brunei will have regard to the $350 \mathrm{~nm}$ constraint line, ibid, at 7. This constraint line in the case of Brunei actually lies landward of the constraint line of $100 \mathrm{~nm}$ beyond the 2500 meters isobath that thus could also be employed by Brunei. The $350 \mathrm{~nm}$ constraint line is a considerable distance seaward of what in the past has been identified as the possible extent of Brunei's continental shelf claim. That claim reportedly extended to a median line with Viet Nam and was up to $240 \mathrm{~nm}$ from the coast of Brunei, see V Prescott and C Schofield, 'Undelimited Maritime Boundaries of the Asian Rim in the Pacific Ocean', in (2001) 3:1 IBRU Maritime Briefing, at 6.

56 Preliminary submission Brunei, supra note 28, at 4.

57 Ibid, at 7.

58 Rules of Procedure, Annex I, at para 1, supra note 20. 
of the Commission, the question whether the CLCS should constitute a sub-commission to consider the joint submission of Malaysia and Viet Nam and Viet Nam's submission will present itself in the next couple of years. This leaves a period of time in which the States concerned may seek to work towards an arrangement that would allow all of them to give their prior consent to the consideration of the submissions. That prior consent would enable the Commission to consider the submissions in accordance with paragraph 5(a) of Annex I to its Rules of Procedure. In this case it would not have to take a decision on the question whether or not these are disputes related to the submissions. However, it does not seem likely that such an arrangement will be forthcoming.

What would happen if the parties to the disputes have still not given their prior consent by the time the submissions of Malaysia and Viet Nam are up for consideration by the Commission? The reactions of China and the Philippines indicate that they consider that there are land and maritime disputes which should only lead to the consideration of the submissions with their prior consent. The statements of Malaysia and Viet Nam indicate that they either consider that there are no disputes related to the submission or that, if there were to be such disputes, paragraph 5(b) of Annex I to the Rules of Procedure offers a sufficient safeguard for third States. Consequently, in their view, the Commission can consider the submissions. In the absence of prior consent, the CLCS will have to take a decision on the question whether or not the disputes are related to the submissions and whether or not it can consider the submissions. The CLCS would be competent to assess how it should interpret and apply its Rules of Procedure. Article 9 of Annex II to UNCLOS suggests that the Commission should take a cautious approach in deciding on that matter. $^{59}$

The reaction of China to the two submissions indicates that it considers that there exists a dispute related to the sovereignty over islands and the status of the waters of the South China Sea. The reaction of the Philippines in regard to the submission of Viet Nam indicates that the Philippines considers that there exists a dispute concerning the delimitation of maritime boundaries. As regards the joint submission, the Philippines moreover has submitted that there exists a territorial dispute. There can be little doubt that Annex I to the Rules of Procedure is intended to cover the types of

59 See also TL McDorman, 'A Note on the Commission on the Limits of the Continental Shelf and the Submission of the Russian Federation' in DD Caron and HN Scheiber, eds, Bringing New Law to the Oceans (Leiden: Martinus Nijhoff Publishers, 2004) 467, at 480-481. 
disputes to which China and the Philippines have made reference. Annex I explicitly refers to disputes 'in the delimitation of the continental shelf'. The reference to land disputes presumably is intended to refer to disputes concerning the title to territory. A finding of the Commission that there are disputes related to the submission would likely imply that it will not consider the submissions. In a number of instances a coastal State and another State have differed over the question whether there existed a dispute related to a submission that would trigger the application of paragraph 5 of the Commission's Rules of Procedure. In the majority of these cases, the Commission decided that it would not consider the submission or proceed to establishing a sub-commission to consider the submission. ${ }^{60}$ However, in the case of Guyana's submission, the Commission seems to have decided that it will in principle proceed with its consideration, notwithstanding the absence of consent of Venezuela. ${ }^{61}$ Available information

60 See the Commission's decision not to consider the partial submission of the United Kingdom in respect of the Falkland Islands and of South Georgia and the South Sandwich Islands, CLCS/66 of 30 April 2010, at paras 55-59, online: daccess-dds-ny.un.org/doc/UNDOC/GEN/N10/337/97/PDF/ N1033797.pdf?OpenElement; the Commission's decision to defer the consideration of Myanmar's submission, CLCS/64 of 1 October 2009, at paras 35-40; CLCS/76 of 5 September 2012, at para 23, online: http://daccess-ods.un.org/ TMP/8378306.03122711.html; CLCS/78 of 1 April 2013, at para 47, online: http:// daccess-ods.un.org/TMP/8367917.53768921.html; and the Commission's decision not to establish a sub-commission to consider the submission of Fiji, CLCS/64 of 1 October 2009, at paras 70-71; CLCS/76 of 5 September 2012, at para 24.

61 There exists a longstanding territorial dispute between Venezuela and Guyana. The disputed area contributes to the generation of the $350 \mathrm{~nm}$ constraint line, which has been used by Guyana to determine the outer limit of its continental shelf, see A Submission of Data and Information on the Outer Limits of the Continental Shelf of the Co-operative Republic of Guyana Pursuant to Part VI of and Annex II to the United Nations Convention on the law of the sea; Executive Summary, at 9-10, online: www.un.org/Depts/los/clcs_new/sub missions_files/guy57_11/GUY_Executive\%20Summary.pdf. Venezuela objected to the submission of Guyana and its consideration by the Commission having regard to the Rules of Procedure of the Commission (communication of 9 March 2012), at 2, online: www.un.org/Depts/los/clcs_new/submissions_files/guy57_11/ clcs57_2011_ven_e.pdf. Guyana in its presentation to the Commission submitted that there were no territorial or maritime boundary disputes or controversies that might affect the consideration of Guyana's submission, see CLCS/74 of 30 April 2012, at para 41, online: http://daccess-ods.un.org/TMP/2223335.65354347.html>. Following Guyana's presentation, the Commission decided that:

'the submission would be addressed by a subcommission to be established in accordance with rule 51, paragraph 4 ter, of the Rules of Procedure, at a future session. The Commission also decided that it would revert to the consideration 
does not allow establishing the reasons for the difference between the former cases and that of Guyana. ${ }^{62}$

What are the options for a State to deal with a deadlock in the consideration of its submission because another State has invoked the existence of a dispute related to the submission and refuses to give its consent? Part XV of the Convention provides that States Parties shall settle any dispute between them concerning the interpretation or application of the Convention by peaceful means. ${ }^{63}$ Where no settlement has been reached by recourse to section 1 of Part XV of the Convention, any dispute concerning the interpretation or application of the Convention can be submitted at the request of any party to the dispute to compulsory dispute settlement. ${ }^{64}$ Section 3 of Part XV establishes certain limitations on and exceptions to the applicability of compulsory dispute settlement procedures. Article 76 is not covered by these limitations and exceptions. ${ }^{65}$ During the 2013 CIL Roundtable, ${ }^{66}$ some commentators suggested that one should take a broad reading of the reference to sea boundary delimitations in Article 298 of the Convention concerning optional exceptions to the applicability of compulsory dispute settlement mechanisms and that this reference also covers Article 76. However, it should be noted that Article 298(1)(a)(i) explicitly refers to 'disputes concerning the interpretation of application of Articles 15, 74 and 83 relating to sea boundary delimitations'. In Bangladesh/Myanmar the International Tribunal for the Law of the Sea (ITLOS) recognized that entitlement and delimitation are interrelated, but observed that 'entitlement and delimitation are

of the submission at the plenary level when the submission was next in line for consideration as queued in the order in which it was received', see ibid, at para 42.

62 One difference is that Venezuela is the only State in this sample that is not a party to UNCLOS. The report on the presentation of Guyana's submission does not suggest that this fact played a role in the Commission's decision, see CLCS/74 of 30 April 2012, at paras 41-42. The Commission's treatment of comments that were submitted by the United States, another State that is not a party to UNCLOS, in relation to the submission of Brazil also do not suggest that the Commission considered that it should disregard these comments because the United States was not a party to the Convention, see CLCS/42 of 14 September 2004, at para 17, online: http://daccess-ods.un.org/TMP/2223335.65354347.html.

63 UNCLOS, Art 279.

64 UNCLOS, Art 286.

65 See further Committee on Legal Issues of the Outer Continental Shelf, 'Report' in International Law Association, Report of the Seventy-First Conference (London, 2004) 773, at 782-783.

662013 CIL Roundtable on the South China Sea, International Law and UNCLOS conducted in Singapore, 27-28 June 2013. 
two distinct concepts addressed respectively in Articles 76 and 83 of the Convention' ${ }^{67}$

A court or tribunal first of all can be expected to make a distinction between the Commission and the third State, which has not given its prior consent to the consideration of a submission. ${ }^{68}$ A case before a court or tribunal would be between the submitting State and the third State which has not given its prior consent to the consideration of the submission. The Commission would not be a party to these proceedings. The Convention does not envisage that the Commission may participate as a party to third party dispute settlement procedures under the Convention. ${ }^{69}$ This implies that the possibilities for a court or tribunal to review the actions of the Commission are limited.

As a general rule, a court or tribunal is not excluded from exercising its jurisdiction because a dispute involves a decision by a body such as the Commission. It has been observed that:

The CLCS is competent to take decisions on such matters as its rules of procedure. In this case, the rules that generally apply to exercise of jurisdiction in a contentious case involving the incidental consideration of a decision by an international body apply. A court or tribunal is competent to establish if the Commission has overstepped the bounds of its competence as defined in the Convention, applying a test of reasonableness. This test may lead to the conclusion that the Commission has acted within the limits of its competence or ultra vires, or that a decision is invalid for other reasons. ${ }^{70}$

It seems to be highly unlikely that a court or tribunal would conclude that the Commission would have overstepped the bounds of its competence by concluding that because of the absence of the prior consent of a State which is a party to a land or maritime dispute, it may not consider a submission. Article 9 of Annex II to UNCLOS requires that the actions of the Commission shall not prejudice matters relating to the delimitation of maritime boundaries between States with opposite or adjacent coasts. The

67 Dispute concerning Delimitation of the Maritime Boundary between Bangladesh and Myanmar in the Bay of Bengal (Bangladesh/Myanmar), [2012] ITLOS Reports 4 (Bangladesh/Myanmar), at para 398.

68 For a discussion of third party dispute settlement in relation to Art 76 of the UNCLOS see also B Kunoy, 'Legal Problems relating to Differences Arising between Recommendations of the CLCS and the Submission of a Particular State' in CR Symmons, ed, Selected Contemporary Issues in the Law of the Sea (Leiden: Martinus Nijhoff Publishers, 2011) 305.

69 See Committee on Legal Issues of the Outer Continental Shelf, 'Report', supra note 65 , at 784 .

$70 \quad$ Ibid, at 786. 
reference to 'matters relating to' is broad enough to cover the issues raised by China and the Philippines. The Commission is competent to decide how it is to guarantee that its actions shall not prejudice these matters. In certain cases it would not be unreasonable to conclude that this might require not considering a submission without the prior consent of all the States concerned.

Article 9 of Annex II to the Convention has been implemented by the Commission through Rule 46 of and Annex I to its Rules of Procedure. Annex I was brought to the attention of the States Parties to the Convention and there was no objection to the proposed approach contained in draft Annex I as such. Annex I has been widely used by States Parties in the implementation of Article 76 of the Convention. Numerous States have availed themselves of the opportunity to inform the Commission of their views concerning disputes related to a submission in accordance with Annex I to the Rules of Procedure. In this connection, no State has objected against the provisions contained in Annex $\mathrm{I}^{71}$ This practice can be viewed as subsequent practice in the application of the Convention which establishes the agreement regarding the interpretation of Article 9 of Annex II to the Convention. ${ }^{72}$ These arguments indicate that a court or tribunal would likely find that the CLCS is competent to decide to refrain from considering a submission in the absence of the prior consent of all of the parties to the land or maritime dispute related to a submission as this is in accordance with Article 9 of Annex II to the Convention and the Commission's Rules of Procedure.

The conclusion may be different in relation to a State that has not given its prior consent to the consideration of a submission. According to paragraph 5(a) of the Commission's Rules of Procedure, the consideration of a submission in certain circumstances is only possible with the prior consent of other States. No such limitation is included in UNCLOS. In order to properly assess the consequences of paragraph 5 , it has to be considered in light of the relevant provisions of the UNCLOS. The Rules of Procedure are subordinate to UNCLOS. ${ }^{73}$ As was discussed above, the result of

71 This assessment is based on the information that is available on the reactions of States to submissions on the website of the CLCS. Not all communications in relation to submissions are available through the website of the CLCS, see for instance the communications mentioned in CLCS/78 of 1 April 2013, at para 3(e).

72 See Vienna Convention on the Law of Treaties, adopted 23 May 1969, 1155 UNTS 331 (entered into force 27 January 1980), Art 31(3)(b).

73 See also Letter dated 25 August 2005 from the Legal Counsel, UnderSecretary-General of the United Nations for Legal Affairs, CLCS/46 of 7 September 2005, at 8, online: http://daccess-ods.un.org/TMP/7942333.81748199.html. 
Article 76(10) of the Convention is that the provisions in Article 76(8) and 76(9) concerning the final and binding and permanent nature of outer limits of the continental shelf cannot be invoked against another State where the delimitation of the continental shelf is concerned. In light of this provision, it is submitted that other States should in principle accept the consideration of a submission by a coastal State that raises issues of delimitation of the continental shelf. That consideration and subsequent recommendations will not prejudice their rights. ${ }^{74}$

Annex I to the Rules of Procedure of the CLCS not only addresses submissions involving the delimitation of the continental shelf between neighbouring States, but also refers to other land and maritime disputes. In the latter case the rights of other States are not explicitly safeguarded by the Convention. However, other States have the possibility to indicate their views either directly to the coastal State or to the Commission in reaction to a submission. It could be argued that this would in principle be sufficient to safeguard their rights. That view is also expressed by paragraph 5(b) of the Rules of Procedure, which provides that the submission before the Commission and its recommendations shall not prejudice the position of States which are parties to the land or maritime dispute. In that light it could be argued that a State in principle should not withhold its prior consent to the consideration of a submission by the Commission.

The conclusion that paragraphs 5(a) and 5(b) of the Commission's Rules of Procedure are not intended to give third States a veto power in regard of the submission of a coastal State is confirmed by the consideration of Annex I at the Eighth Meeting of States Parties to the Convention. According to the Report of the Eighth Meeting only two delegations made observations. One delegate remarked that the Rules of Procedure should: 'not appear to create new rights for States that are only defined by the Convention ... The Chairman [of the Commission] agreed that editorial changes would be introduced in order to make it clear that the rules deal only with the procedure of the Commission' ${ }^{75}$ The Convention does not

74 See further AG Oude Elferink and C Johnson, 'Outer Limits of the Continental Shelf and "Disputed Areas": State Practice concerning Article 76(10) of the LOS Convention' (2006) 21 Int'l J Mar \& Coast L 461; see also CR Symmons, 'The Irish Partial Submission to the Commission on the Limits of the Continental Shelf in 2005: A Precedent for Future Submissions in the Light of the "Disputed Areas" Procedure of the Commission?' (2006) 37 Ocean Devel \& Int'1 L 299, at 309.

75 SPLOS/31 of 4 June 1998, at para 48, online: daccess-dds-ny.un.org/doc/ UNDOC/GEN/N98/161/23/PDF/N9816123.pdf?OpenElement. 
envisage that a third State may block the consideration of a submission of a coastal State. ${ }^{76}$

\section{THE STATUS OF THE CONTINENTAL SHELF BEYOND 200 NAUTICAL MILES IN THE ABSENCE OF FINAL AND BINDING LIMITS}

The absence of final and binding limits raises the question of what legal regime applies to the continental shelf beyond $200 \mathrm{~nm}$ in the meantime. UNCLOS does not explicitly address the question of whether or not a coastal State is entitled to exercise its rights over the continental shelf beyond $200 \mathrm{~nm}$ before final and binding limits have been established. However, a number of provisions support the former position. Article 77(3) of UNCLOS provides that the 'rights of the coastal state over the continental shelf do not depend on occupation, effective or notional, or any express proclamation'. In other words, the rights of the coastal State also do not depend on the establishment of the outer limits of the continental shelf in accordance with Article 76 of UNCLOS. Article 76 itself points to this same conclusion. Article 76(1) provides that the continental shelf extends to the outer edge of the continental margin or to a distance of $200 \mathrm{~nm}$ where the outer edge of the continental margin does not extend to that distance. Article 76(4) requires the coastal State to determine the outer edge of the continental margin wherever the continental margin extends beyond $200 \mathrm{~nm}$. It is this process of establishing the outer edge of the continental margin which is the subject of the procedure involving the CLCS. As Article 76(4) indicates, this process is premised on the presence of a pre-existing continental shelf entitlement. The task of the Commission is not to validate the entitlement to the continental shelf beyond $200 \mathrm{~nm}$, but only to determine whether the outer limits of this entitlement have been established in accordance with Article 76. The entitlement either exists or does not exist. Obviously, in the latter case the Commission should conclude that it cannot recommend that a coastal State establish outer limits beyond $200 \mathrm{~nm} .{ }^{.7}$

76 For further discussion of this issue see Oude Elferink, Causes, supra note 1 , at $270-271$.

77 In respect of the continental shelf of Ascension Island, the Commission in its recommendations concluded that the submission of the United Kingdom did not provide a basis for establishing outer limits beyond $200 \mathrm{~nm}$, see Commission on the Limits of the Continental Shelf, Summary of the Recommendations of the Commission on the Limits of the Continental Shelf in regard to the Submission 
Article 76(2) also supports the view that the entitlement to the continental shelf is not dependent upon the establishment of outer limits on the basis of the recommendations of the CLCS. Article 76(2) provides that the continental shelf of a coastal state shall not extend beyond the limits provided for in Article 76(4)-(6). It does not refer to paragraphs 7 to 9 of Article 76, thus indicating that a continental shelf entitlement already exists up to the limits contained in paragraphs 4 to 6 before a coastal State has implemented paragraphs 7 to 9 .

There is a significant amount of State practice that supports the view that the entitlement to a continental shelf beyond $200 \mathrm{~nm}$ exists in the absence of final and binding limits. However, certain States take the view that these continental shelf rights do not exist prior to the establishment of outer limits in accordance with Article 76 of UNCLOS. A more detailed analysis of State practice would be required to determine its significance with greater certainty. ${ }^{78}$

If the rights to the continental shelf beyond $200 \mathrm{~nm}$ do not depend on the establishment of final and binding outer limits, a further question is how the extent of this part of the continental shelf can be defined provisionally. ${ }^{79}$ One possible approach would be that there should be a presumption that in the absence of final and binding limits, the limits contained in the submission of a coastal State to the Commission shall be considered to be the outer limits of its continental shelf. A difficulty with this approach might be that the limits contained in the submission may not become the final and binding limits of the continental shelf in accordance with Article 76(8). In a number of cases the CLCS has not adopted the limits submitted by the coastal State. ${ }^{80}$ Another consideration in this

Made by the United Kingdom of Great Britain and Northern Ireland in respect of Ascension Island on 9 May 2008 (15 April 2010), at para 54, online: www.un.org/ depts/los/clcs_new/submissions_files/gbr08/gbr_asc_isl_rec_summ.pdf. The United Kingdom had submitted outer limits extending up to $350 \mathrm{~nm}$ from Ascension.

${ }_{78}$ For a further discussion see Oude Elferink, The Regime, supra note 1, at 193-199. This article also reviewed the jurisprudence concerning this issue and concluded that there existed a certain hesitance in dealing with the delimitation of the continental shelf beyond $200 \mathrm{~nm}$ in the absence of outer limits established in accordance with Art 76 of UNCLOS, ibid, at 199-201. This matter was addressed in detail by ITLOS in Bangladesh/Myanmar. The Tribunal concluded that the absence of outer limits established in accordance with Art 76 of UNCLOS did not bar it from effecting a delimitation of the continental shelf beyond $200 \mathrm{~nm}$ between the parties, see Bangladesh/Myanmar, supra note 67, at paras 369-394.

79 For a more detailed discussion of this issue see Oude Elferink, The Regime, supra note 1, at 202-203.

80 See for instance the case of Ascension, supra note 77. 
connection would be that the establishment of the limits of maritime zones is not a completely unilateral process only involving the coastal State. After a coastal State has established a maritime limit, other States have a right to reject it on the ground that it is not in conformity with international law. ${ }^{81}$ This also would be the case where a coastal State invokes the limits it has submitted to the CLCS as the provisional limits of its continental shelf pending the outcome of the consideration of its submission by the Commission. There is no obligation for other States to accept such provisional outer limits if they consider that they are not in accordance with the substantive provisions of Article 76.

A further question is whether the coastal State is entitled to exercise rights over the continental shelf beyond $200 \mathrm{~nm}$ in the absence of final and binding limits. Article 77 of UNCLOS defines the rights of the coastal State over the continental shelf. Article 77 does not make a distinction between the continental shelf within and beyond $200 \mathrm{~nm}^{82}$ and explicitly refers to the exercise of these rights. There thus does not seem to be scope for other States to object to the exercise of these rights by the coastal State over the continental shelf beyond $200 \mathrm{~nm}$ as such. However, other States may object if a State is exercising continental shelf rights in an area which they consider to be beyond the outer limits of the continental shelf. ${ }^{83}$

What legal consequences would a dispute over the exercise of continental shelf rights by a State have? It will be up to the States concerned to seek a solution to such a dispute. In the case of overlapping continental shelf entitlements, the coastal States concerned have an obligation, pending agreement on a final delimitation, to make every effort to enter into pro-

81 As the ICJ observed in the Anglo-Norwegian Fisheries case concerning the straight baselines Norway had established along its coast, 'The delimitation of sea areas has always an international aspect; it cannot be dependent merely upon the will of the coastal State as expressed in its municipal law. Although it is true that the act of delimitation is necessarily a unilateral act, because only the coastal State is competent to undertake it, the validity of the delimitation with regard to other States depends upon international law', see Fisheries Case (United Kingdom $v$ Norway) [1951] ICJ Reports 116, at 132.

82 See also Bangladesh/Myanmar, supra note 67, at para 361.

83 After the outer limits of the continental shelf have been determined in accordance with Art 76 of UNCLOS, it could become clear that a State has exercised continental shelf rights in an area beyond these outer limits. This would constitute an unlawful act, which, depending on the circumstances of the case, could give rise to a requirement for reparation. For instance, if a State has exploited the mineral resources of a claimed continental shelf area, which is subsequently established to be part of the Area, the International Seabed Authority would be entitled to claim damages, see UNCLOS, Art 137. 
visional arrangements and not to jeopardize or hamper the reaching of the final agreement. ${ }^{84}$

If negotiations do not result in a solution, UNCLOS offers States the possibility of submitting a dispute to compulsory dispute settlement. A court or tribunal in such a case will be required to decide if continental shelf rights exist in the area concerned. There is one important limitation in addressing this issue. A court or tribunal would not be competent to deal with matters falling within the competence of the CLCS and would not be in a position to make recommendations to coastal States. On the other hand, a court or tribunal would be competent to deal with other questions in respect of Article 76.

\section{THE IMPLICATIONS OF THE PARACEL ISLANDS AND THE SPRATLY ISLANDS FOR THE CONTINENTAL SHELF BEYOND 200 NAUTICAL MILES}

A $200 \mathrm{~nm}$ limit measured from the Paracel Islands and the Spratly Islands extends into the area that is the subject of the joint submission of Malaysia and Viet Nam and Viet Nam's submission for the North Area. This raises the question how the entitlement of the islands to a $200 \mathrm{~nm}$ zone relates to the continental shelf entitlement beyond $200 \mathrm{~nm}$. This question was at issue between Bangladesh and Myanmar in the case concerning the maritime boundary that was decided by ITLOS in its judgment of 14 March 2012. Bangladesh had submitted that its continental shelf extended beyond 200 $\mathrm{nm}$ and requested to delimit this part of its continental shelf in relation to Myanmar. On the other hand, Myanmar contended that Bangladesh was not entitled to a continental shelf beyond $200 \mathrm{~nm}$ because recognizing such an entitlement would be against the rights Myanmar enjoyed automatically to a continental shelf within $200 \mathrm{~nm}$ and Myanmar's right to extend its EEZ to the outer limit of $200 \mathrm{~nm}$ under UNCLOS. ${ }^{85}$ This position is based on the view that the continental shelf beyond $200 \mathrm{~nm}$ of one State cannot extend into the $200 \mathrm{~nm}$ zone of another State. It seems unlikely that China would advance a similar argument in respect of the South China Sea in view of its position on the continental shelf in the East China Sea. ${ }^{86}$

Before answering the question on the relationship between the $200 \mathrm{~nm}$

\footnotetext{
84 UNCLOS, Art 83(3).

85 See Bangladesh/Myanmar, supra note 67, at paras 468-469.

86 See supra note 43.
} 
zone and the continental shelf beyond $200 \mathrm{~nm}$, the Tribunal first effected the delimitation of the continental shelf boundary beyond $200 \mathrm{~nm}$. In this context, the Tribunal observed that 'article 76 of the Convention embodies the concept of a single continental shelf ${ }^{87}$ The Tribunal also observed that Article 77 on the exercise of sovereign rights by the coastal State and Article 83 on the delimitation of the continental shelf do not make any distinction between the continental shelf within and beyond $200 \mathrm{~nm} .{ }^{88}$

After the Tribunal had effected the delimitation of the continental shelf beyond $200 \mathrm{~nm}$ between the parties, it considered the consequences of the fact that a part of this boundary was located within the EEZ of Myanmar. The Tribunal observed that there was no question of delimiting the EEZ between Bangladesh and Myanmar as there was no overlap with the EEZ of Bangladesh. ${ }^{89}$ The Tribunal further observed that UNCLOS makes a distinction between the rights of the coastal State over the water column and over the seabed and subsoil. The Tribunal concluded that the continental shelf boundary delimited the rights of the parties in respect of the seabed and subsoil of the continental shelf but did not limit Myanmar's rights over the water column of the EEZ. ${ }^{90}$

The application of these findings of the Bangladesh/Myanmar case to the South China Sea points to a number of considerations. Any island of the Paracel Islands and the Spratly Islands that does not fall under the definition of a rock under Article 121(3) of the Convention is entitled to an EEZ. To the extent this EEZ overlaps with the continental shelf beyond $200 \mathrm{~nm}$, the State that has sovereignty over the island concerned is entitled to exercise water column rights within the area concerned. In the case of the continental shelf, a delimitation would have to be carried out between the mainland coasts and the islands concerned. In light of the jurisprudence of the ICJ and arbitral tribunals, it would seem likely that individual islands in such a delimitation would be given no weight. ${ }^{91}$

87 Bangladesh/Myanmar, supra note 67, at para 361.

88 Ibid.

89 Ibid, at para 471.

90 Ibid, at paras 473-474.

91 See eg North Sea Continental Shelf Cases (Federal Republic of Germany/ Denmark; Federal Republic of Germany/ Netherlands), [1969] ICJ Reports 51, at para 57; Case Concerning the Continental Shelf (Libyan Arab JamahiriyalMalta), [1985] ICJ Reports 13, at para 64; Arbitration between Eritrea and Yemen (second phase), Award of 17 December 1999, at para 147, online: http://www.pca-cpa.org/ showpage.asp?pag_id=1160; Territorial and Maritime Dispute between Nicaragua and Honduras in the Caribbean Sea (Nicaragua v Honduras), [2007] ICJ Reports 659, at paras 302-305. Case Concerning Maritime Delimitation in the Black Sea (Romania v Ukraine), [2009] ICJ Reports 61 (Black Sea), at paras 149 and 188; 
However, the case law also indicates that individual islands - including those that fall under the definition of Article 121(3) of UNCLOS - and low-tide elevations within $12 \mathrm{~nm}$ of these islands would be entitled to a 12-nm territorial sea. ${ }^{92}$

\section{CONCLUSIONS}

The existence of a continental shelf beyond $200 \mathrm{~nm}$ from the coasts surrounding the South China Sea has important implications for the disputes over the Paracel Islands and the Spratly Islands. Without this continental shelf entitlement, the central part of the South China Sea would be part of the continental shelf of the Paracel and Spratly Islands. As this chapter indicates, the continental shelf beyond $200 \mathrm{~nm}$ co-exists with the $200 \mathrm{~nm}$ zones of the Paracel and Spratly Islands. This continental shelf entitlement is not dependent on the establishment of its outer limits in accordance with the procedure set out in Article 76 of UNCLOS, but already exists prior to the completion of that procedure. The overlap of the continental shelf entitlements of the Paracel Islands and the Spratly Islands and the surrounding coasts implies that a delimitation is required. In light of the jurisprudence of the ICJ and arbitral tribunals it would seem likely that individual islands in such a delimitation would be given no weight. However, the case law also indicates that individual islands and low-tide elevations within $12 \mathrm{~nm}$ of these islands would be entitled to a 12-nm territorial sea. Where the EEZ of one of the Paracel Islands or the Spratly Islands overlaps with the continental shelf beyond $200 \mathrm{~nm}$, the State that has sovereignty over that island is entitled to exercise water column rights within the area concerned.

Viet Nam and Malaysia have submitted information to the CLCS on the outer limits of the continental shelf beyond $200 \mathrm{~nm}$ in the South China Sea and Brunei has submitted preliminary information on its continental shelf beyond $200 \mathrm{~nm}$. This step might at first sight seem somewhat surprising as far as Malaysia and Viet Nam are concerned, as it implies that the islands they claim in the South China Sea are not entitled to a continental

Territorial and Maritime Dispute (Nicaragua v Colombia), [2012] ICJ Reports 50, at para 202.

92 See Nicaragua v Honduras, ibid, at para 302; Black Sea, ibid, at para 188; see in particular Nicaragua $v$ Colombia, ibid, at para 238 in relation to the $12 \mathrm{~nm}$ entitlement of a feature on the bank of Quitasueño, which according to the Court fell within the rule of Art 121(3) of UNCLOS, and of low-tide elevations within 12 $\mathrm{nm}$ of this rock. 
shelf. Very few States have taken this position in respect of islands that are part of their territory. However, this step makes sense if it is assessed in a broader law of the sea framework. The existence of a continental shelf extending beyond $200 \mathrm{~nm}$ implies that the entitlement of the Paracel Islands and the Spratly Islands to the seabed area that is only within 200 $\mathrm{nm}$ of the islands is not exclusive. ${ }^{93}$ If the law were to play a role in the eventual solution of the sovereignty and delimitation disputes involving the islands, this fact should give Malaysia and Viet Nam a larger share of the continental shelf of the South China Sea than in the case of the absence of this entitlement beyond $200 \mathrm{~nm}$. That Brunei takes the same approach is hardly surprising from this perspective. The only feature it claims is Louisa Reef, which at most seems to qualify as a rock under Article 121(3) of UNCLOS. China and the Philippines have left the option to make a submission to the CLCS open. In the case of the Philippines a similar argument would apply as for Malaysia and Viet Nam. China's position on continental shelf entitlement in the South China Sea may be influenced by two legal considerations. In view of its position in the East China Sea, where it claims a continental shelf beyond $200 \mathrm{~nm}$ that overlaps with Japan's $200 \mathrm{~nm}$ zone, it would be inconsistent to reject a similar position of other States in the South China Sea. Secondly, China also has an interest in maintaining the option of asserting a continental shelf entitlement beyond $200 \mathrm{~nm}$ in the South China Sea. Interestingly, the possibility of making a partial submission created by the Rules of Procedure of the CLCS has allowed China to remain ambiguous in respect of this issue. The assertion of the existence of a continental shelf beyond $200 \mathrm{~nm}$ would make it possible for China to claim a part of the central area of the South China Sea as part of the continental shelf extending from Hainan Island. It would not seem unreasonable to submit that Hainan in a delimitation should receive similar treatment as other coasts surrounding the South China Sea.

The refusal of China and the Philippines to give their consent to the consideration by the CLCS of the joint submission of Malaysia and Viet Nam and Viet Nam's submission for the North Area is unlikely to negate the significance of the lodging of these submissions with the Commission.

93 It should be acknowledged that this position does imply the renunciation of rights over the water column that is only within $200 \mathrm{~nm}$ of the islands. Under the approach of Viet Nam and Malaysia, that area would be part of the high seas. In view of the fact that this would concern a high seas enclave, the surrounding coastal States would likely have a significant role to play in fisheries management of that area. For some examples of the fisheries regimes of such high seas enclaves see OS Stokke, ed, Governing High Seas Fisheries; The Interplay of Global and Regional Regimes (Oxford University Press, 2001), at 143-206 and 273-302. 
Malaysia and Viet Nam by making the submissions have clearly marked their position that the existence of a continental shelf entitlement beyond $200 \mathrm{~nm}$ is part of the territorial and maritime disputes in the South China Sea. ${ }^{94}$ As long as other disputants block the consideration of the two submissions by the CLCS, they cannot credibly argue that the case of Malaysia and Viet Nam is not in accordance with the substantive provisions of Article 76 of UNCLOS as they themselves prevent the CLCS from considering that matter. Viet Nam and Malaysia might attempt to get a ruling under Annex VII that the withholding of consent by China and the Philippines is not in accordance with UNCLOS. However, in light of the uncertainty of the outcome of such a procedure, and the fact that their continental shelf entitlement beyond $200 \mathrm{~nm}$ is not dependent on the establishment of outer limits and they have made their case by applying the substantive provisions of Article 76, the advantages of getting a positive ruling do not seem to outweigh the risks of seeing it rejected.

The obligations of States Parties to UNCLOS to submit information on the outer limits of their continental shelf in accordance with Article 76 has brought the significance of continental shelf entitlements beyond $200 \mathrm{~nm}$ clearly into focus in the South China Sea. The existence of these entitlements is likely to continue to play a role in considering the legal aspects of the disputes in the South China Sea.

94 See also McDorman, supra note 25, at 534. 